\title{
Language and language-in-education planning in multilingual India: a minoritized language perspective
}

\author{
Cynthia Groff ${ }^{1}$
}

Received: 10 March 2015/Accepted: 14 December 2015/Published online: 10 March 2016

(C) The Author(s) 2016. This article is published with open access at Springerlink.com

\begin{abstract}
This article explores India's linguistic diversity from a language policy perspective, emphasizing policies relevant to linguistic minorities. The Kumaun region of Utterakhand provides a local, minority-language perspective on nationallevel language planning. A look at the complexity of counting India's languages reveals language planning implicit in the Indian census. The more explicit status planning involved in the naming of official languages is explored in the Indian Constitution. An overview of India's language-in-education policies for languages to be taught and languages to be used as media of instruction further illustrates status and acquisitions planning affecting India's linguistic minorities. The Indian example informs and stretches the language planning frameworks used to analyze it, adding status-planning goals of legitimization, minimization, and protection. Finally, the question of what actually happens in education for linguistic minorities opens up a conversation about the pluralistic language practices common in multilingual contexts beyond the implementation of official language and education policies.
\end{abstract}

Keywords Language policy and planning - Linguistic minorities - Medium of instruction · Minority education · Indian census · Indian Constitution · Legitimate language

\section{Introduction: Languages and linguistic minorities in India}

Known to be a diverse country of multiple cultures and multiple languages, India has faced the challenge of dealing with this resource called diversity. While the questions of how many languages there are in India, which of those languages get

Cynthia Groff

cgroff@alumni.upenn.edu

1 Leiden University Centre for Linguistics, Postbus 9515, 2300 RA Leiden, The Netherlands 
status, which languages are used for teaching and which languages are taught are interesting in themselves, perhaps more important is a focus on how the Indian nation has chosen to answer those questions and how these answers, being instances of language planning, influence the lives of linguistic minorities.

Linguistic minorities here refers broadly to those people whose language or spoken variety is either not recognized by the government at the national level or is not the recognized regional language where they live. Although I use the term "minorities" in this paper for clarity and to follow the common discourse in the literature that I site, the adjective "minoritized" seems more appropriate for describing these languages and people groups, especially in light of the active minimization of languages and the lack of legitimization and protection in language planning described below. Speakers of minoritized languages may not necessarily be numerical minorities in their region. Some groups considered to be linguistic minorities in India since their language is not among the 22 nationally recognized languages have populations of over 3 million (King 1997), populations exceeding those of some European countries. Other linguistic minorities, referred to as relative minorities, are those whose mother tongue is official in another state but not in the state where they are living (Ekbote 1984). Urdu speakers scattered across India are often relative minorities, and their position has been given special consideration in issues of language in education. In fact, the term "minority" is often used in India to refer to the Muslim population alone, most of whom claim Urdu as their mother tongue.

The language planning decisions bearing the most immediate implications for linguistic minorities are those that affect their educational opportunities. The literacy rates for cultural and linguistic minorities in India have tended to be significantly below average, while drop-out rates tend to be high among these groups. Jhingran (2005: 3) estimates that in India "almost 25 percent of all primaryschool-going children face a moderate to severe learning disadvantage owing to their language background." Children who do not fully understand the language of instruction may be learning a dominant language by submersion but miss out on content learning. Language and cultural differences also fuel miscommunication between students and teachers (see Hornberger 2003; Khubchandani 2005; Mohanty 2005; Skutnabb-Kangas et al. 2009).

This article explores some of India's linguistic diversity from a language planning perspective, particularly emphasizing language policies relevant to linguistic minorities and their educational opportunities. First, the complexity of counting and reporting the number of Indian languages reveals the language planning that is implicit in Indian census procedures. Next, the more explicit status planning involved in the naming of official and recognized languages is explored through analysis of the Indian Constitution. The Constitution also contains important safeguards protecting the rights of cultural and linguistic minorities, including their educational rights. In addition, India's national language-ineducation policies, both for languages to be taught in school and for languages to be used as media of instruction in schools, provide direction for the states in formulating their own language-related educational policies. The implications of 
this national-level language planning for linguistic minorities are exemplified through the case of the Kumaun.

From an international perspective, India's language policies may be applauded as exceptionally multilingual. Indeed, India's acceptance and promotion of linguistic diversity contrasts with the policies of many nations that have promoted the status of a single national language, and concern for the educational needs of linguistic minorities in India has been increasing in recent years. Yet, much of the linguistic diversity in India remains hidden and unlegitimized. Vigilance is needed in protecting the status of minoritized languages and insuring justice, particularly just access to education, for speakers of all linguistic varieties. Besides demonstrating the practical need for caution in language planning and policy, the Indian example informs and stretches the language planning and policy frameworks used to analyze it. I describe the national-level policies and practices relevant to linguistically minoritized groups in India from a historical perspective, demonstrating contradictions in explicit and implicit language policies, and illustrating the on-the-ground consequences experienced and expressed by Kumauni speakers in North India.

\section{Language planning and ethnography in the Kumaun}

The local perspective offered in this article comes from interviews and participant observation with Kumauni people of the Himalayan foothills of Uttarakhand. Kumauni is an Indo-Aryan language linguistically classified in the Central Pahari language group, which also includes neighboring Garhwali. It is also similar to the Pahari variety spoken across the border in Nepal, just east of the Kumaun. A 1999 sociolinguistic survey reported an estimated 2.36 million speakers of Kumauni, a vital language used for daily communication particularly in rural areas (Bailey et al. 1999). Kumauni is not listed among the 22 recognized languages in the Indian Constitution and is (thus) often considered by Indians to be a dialect of Hindi, an issue that I found to be significant to local views regarding its status.

My ethnographic research in the Kumaun focused on the views and practices of Kumauni young women and their educators related to language and education. I spent a total of 14 months in and around the village of Kausani between 2000 and 2008, including 9 months of primary fieldwork in 2007-2008. Living at a Gandhian girls' boarding school, I observed language use and educational practices there and in surrounding schools. Through numerous informal and semiformal interviews with students, teachers, teacher-trainers, and community members, I raised questions about (perceptions of) the language and education situation in the Kumaun. Conversations in villages, at Kumaun University, and at district and state education offices were also important for exploring local experiences and perspectives.

An ethnography of language policy analyzes the connection between macrolevel policy texts and their implications and implementation in specific contexts, where language planning is conducted at more micro levels (Hornberger and Johnson 2007; Johnson 2009; McCarty 2011). My original study had a broader 
scope than an ethnography focused on specific language policies; however, the analysis presented here focuses on the Kumauni situation in relation to the national-level language planning described in each section. Although elsewhere I focus more fully on local perspectives (Groff 2010, forthcoming), the aim here is to use the Kumauni example to shed light on (the implications of) more macrolevel language planning. Also not discussed here are various meta-level contexts of language planning, including the state and university. Uttarakhand named Hindi and Sanskrit as its official languages in 2010, and legislation in 2014 laid the groundwork for the teaching of Kumauni and Garwhali in primary schools by 2017. Kumaun University is meanwhile pleased to expand its Kumauni language courses to fulfill this new demand. The following section describes some theoretical foundations that have influenced my analysis of Indian language planning and the case of the Kumaun.

\section{Language and power in status and acquisition planning}

The integrative framework of language planning goals (Hornberger 1994) provided the initial structure for this analysis of Indian census procedures, constitutional provisions, and educational policies. Building on two decades of language planning scholarship, the framework integrates types and approaches of language planning (see Table 2, below). Hornberger presents the framework within a discussion of literacy development in multilingual nations, encouraging attention to the multiple dimensions of language and literacy planning and explicitly acknowledging what the framework does not show: "that planning for a given language/literacy never occurs in a vacuum with regard to other languages/literacies" (1994: 83).

Language planning and policy is no longer studied as merely a set of texts dictating circumstances from the top down, if it ever was. Rather, LPP is understood as a "multilayered construct," involving active human agents (Ricento and Hornberger 1996; Hornberger and Johnson 2007) and as a "situated sociocultural process" (McCarty 2011). Echoing the study of policy "as a practice of power" (Sutton and Levinson 2001), scholars have begun to investigate language policy "as a practice of power that operates at multiple, intersecting levels: the micro level of individuals in face-to-face interaction, the meso level of local communities of practice, and the macro level of nation-states and larger global forces" (McCarty 2011: 3). These trends follow discussions regarding covert and overt, de jure and de facto, top-down and bottom-up language planning (e.g., Kaplan 1989; Schiffman 1996; Canagarajah 2005). As attention shifts towards the sociopolitical dynamics of LPP, the role of human agents is forefronted as well as the significance of the ideological context (Ricento 2000; Davis 2014).

Language-related decisions and the ways in which particular linguistic varieties are viewed are shaped by language orientations and ideologies (Ruiz 1984; Schieffelin et al. 1998; Irvine and Gal 2000). The often-cited "one-nation, onelanguage" ideology, for example, inspires policies that favor monolingual assumptions rather than valuing multilingualism and multilingual practice. Some ideologies simplify the sociolinguistic field, ignoring some linguistic diversity 
through what Irvine and Gal (2000) call erasure. Issues of power in society are clearly at play when some linguistic varieties and practices are considered to be legitimate and others not (Bourdieu 1991; Heller and Martin-Jones 2001). As Blackledge (2008) points out:

Very often, multilingual societies that apparently tolerate or promote heterogeneity in fact undervalue or appear to ignore the linguistic diversity of their populace. An apparently liberal orientation to equality of opportunity for all may mask an ideological drive towards homogeneity, a drive which potentially marginalises or excludes those who either refuse, or are unwilling, to conform. (36)

In the Indian context, forces of assimilation and the spread of English have altered the ways languages are treated (see e.g., Mohanty 2005; Vaish 2008), in Mohanty's words, obliterating "the traditional complementary relationship between languages and strong maintenance norms" (2005). Similarly, Khubchandani (2005) describes the value of India's traditional "plurilingual milieu," in which "language boundaries remain fuzzy and fluid." Such multilingual contexts are best understood, he says, through "a non-exclusive pluralistic view of speech community" (5).

Ideologies and assumptions about language extend to our norms for talking about and categorizing languages, in what Makoni and Pennycook (2007) refer to as "metalinguistic regimes." Their volume discusses the invention of the concept of language and construction of ways of thinking about language, constructs that have been spread and normalized through colonialism. Of modernism, along with colonization and nationalism, they say: "These movements considered the fluidity and hybridity in precolonial forms of communication a problem and strove to move toward codification, classification and categorization that mark the field of linguistics today" (2007: 233). They call for a disinventing of language that questions the need to classify and count languages as if they were unique entities. Jørgensen (2008) also rejects the notion of languages as "packages which can be counted." In the Indian context, Agnihotri (2007) points out that, for most of the framers of the Indian Constitution, "the existence of 'a language,' as if an autonomous object, was a given. It was difficult for them to appreciate the fact that language is essentially a constantly changing phenomenon, and it is born out of the negotiated dialogue people enter into."

While this article is admittedly focused at a macro level on national-level, topdown influences on language policy and planning, I provide a sample of Kumauni experiences and perspectives, and set the groundwork for future such analysis. Grounded in the theoretical traditions described above, I approach these descriptions with attention to the power dynamics involved and the ideological influences on LPP at all levels. Meanwhile, I consciously keep this discussion open to the disinvention of linguistic categories, though I use those categories to describe, in the following sections, how Indian languages are counted, given status, and used in education. 


\section{How many languages? Status planning through legitimization and minimization}

Describing India's linguistic diversity with an exact number has never been easy. The 2001 Census of India reports 122 languages within India's 28 states and 7 union territories. ${ }^{1}$ Of these languages, 22 are scheduled, or listed in the Constitution. Annamalai (2001) reports that 87 languages are used in the press, 71 on the radio, 13 in the cinema and state administration, and 47 are used as media of instruction. Giving a simple statistic on the number of languages in India is not a simple task, however. Grierson $(1927,1966)$ provided details on Indian languages in a vast 11-volume Survey of Indian Languages. He listed 179 languages and 544 dialects (Sarker 1964). According to Annamalai (2001) India has about 200 total languages reducible from the various dialects. Meanwhile the Ethnologue lists 447 languages still spoken in India and estimates that there could be many more (Lewis et al. 2014). Now gaining recent attention is the People's Linguistic Survey of India, headed by Ganesh Devi and conducted with members of the speech communities, which has collected survey materials for 780 living languages in India (See Anand 2013).

The primary source of information about numbers of languages in India, before the People's Linguistic Survey of India, has been the Indian census, which has been conducted every ten years since 1881 . While the 2001 census listed 122 languages, it also listed 1635 mother tongues, as well as 1957 unclassified "other" mother tongues. The number of mother tongues returned on census forms in the 1961 and 1971 censuses was around 3000, in 1981 there were around 7000, and in 2001 the census returned 6661 mother tongues. How is this striking number of "mother tongues" analyzed in the census? The Registrar General of India had said in 1951 about the complexity of defining and differentiating language and dialect:

"...In view of these doubts and difficulties, it was decided that the Census of India should not be committed to the resolution of any controversy in such matters and the name given by the citizen to his own mother-tongue should be as such and the returns of identical names totaled" (Census of India 1954).

The need, however, for some classification of all of the mother tongues returned can be seen not only in the vast numbers returned but also through a closer look at the returns. In 1951, for example, 73 languages and dialects were listed as spoken by only one person and 137 by two to ten persons. Sometimes mother tongue names are spelled differently, different names are used in different areas for the same spoken variety, caste names are listed instead of language or dialect names, and, interestingly, for a few mother tongues returned on the census all of the speakers were male and for others all of the speakers were female (Sarker 1964). Dua (1986: 135) notes also that sometimes "the notion of mother tongue has been mixed up with region, religion, profession, ethnicity, caste names, and the like." Khubchandani (2001) also mentions the reasons for variations in a person or group's own

\footnotetext{
${ }^{1}$ The language-related data from the 2011 Census of India were not yet released at the time of this writing.
} 
claims and the desire by some to avoid association with a marginalized linguistic variety.

Currently the method for wading through the complexity of census results is described on the Census website as follows:

For assessing the correlation between the mother tongue and designations of the census and for presenting the numerous raw returns in terms of their linguistic affiliation to actual languages and dialects, 6,661 raw returns were subjected to thorough linguistic scrutiny, edit and rationalization. This resulted in 1635 rationalized mother tongues and 1957 names which were treated as 'unclassified' and relegated to 'other' mother tongue category. The 1635 rationalized mother tongues were further classified following the usual linguistic methods for rational grouping based on available linguistic information. (Census of India 2008)

Table 1 provides a visual representation of some of these numbers.

The question of who speaks what language in India starts with the question of what is considered a language. Adding to the complexity, besides differences in what people claim as their mother tongue, are the different definitions of mother tongue. There are linguistic definitions and social definitions of language, and within the latter political definitions must be considered. Defining the differences between language and mother tongue and dialect has been compared to the complexity of defining mountains and hills (Grierson 1927; Sarker 1964). Mother tongue can be defined narrowly or broadly according to Khubchandani (2001). The narrow definition of mother tongue as a child's home language is exemplified in the 1951 Census definition: "The language spoken from the cradle...in the case of infants and deaf mutes... the mother tongue of the mother" (quoted in Khubchandani 2001: 4). The broad definition of mother tongue, on the other hand, classifies all minority languages that have no written form or script as "dialects" of the regional language (2001: 4). Shapiro and Schiffman (1981) also discuss the problems and difficulties of defining language and dialect in India, as well as how certain politically-based definitions, though no longer valid theoretically, tend to remain in force. In the case of the census, further complexity arises as the official definition has changed over the years, including, besides the above definition, the "language spoken by the parents," "language of general use," and "language spoken by the mother" (see Pattanayak 2003).

Table 1 Counting languages in the Indian census (compiled from Census of India 1961, 2008; Dua 1986; Sarker 1964; Singh 2008)

\begin{tabular}{llll}
\hline Year & $\begin{array}{l}\text { Returned mother } \\
\text { tongues }\end{array}$ & $\begin{array}{l}\text { Rationalized mother } \\
\text { tongues }\end{array}$ & Languages \\
\hline 1951 & & 783 & \\
1961 & $\sim 3000$ & 1652 & 193 \\
1971 & $\sim 3000$ & & 105 \\
1991 & $\sim 10,000$ & 1576 & 114 \\
2001 & 6661 & 1635 & 122 \\
\hline
\end{tabular}


The choice of definitions of mother tongue represents an implicit element of language planning. Census officials are not explicitly responsible for forming language policies and yet their decisions influence languages. In a more informal way, individuals who label a language variety as a dialect versus a language also influence the status of that language, deciding on its legitimacy. The classification of a spoken form as a language versus a dialect could be considered an act of status policy planning. In addition, the rationalization process named as a census procedure along with classification also constitutes language planning as it narrows down and names which dialects are available to be classified as languages. Here, Hornberger's (1994) integrative framework of language planning goals becomes useful in categorizing these language-planning acts (see Table 2). Her framework lists a range of status policy goals from less to more restrictive, from standardization to proscription/prohibition. Between these goals could come a language-planning

Table 2 Language planning goals (based on Hornberger 1994)

\begin{tabular}{|c|c|c|}
\hline $\begin{array}{l}\text { Approaches } \\
\text { Types }\end{array}$ & $\begin{array}{l}\text { Policy planning } \\
\text { (on form) } \\
\text { Goals }\end{array}$ & $\begin{array}{l}\text { Cultivation planning (on } \\
\text { function) } \\
\text { Goals }\end{array}$ \\
\hline $\begin{array}{l}\text { Status planning (about uses } \\
\text { of language) }\end{array}$ & $\begin{array}{l}\text { Standardization } \\
\text { Status } \\
\text { Officialization } \\
\text { Nationalization } \\
\text { Legitimization }^{\mathrm{a}} \\
\text { Protection }^{\mathrm{a}} \\
\text { Minimization }^{\mathrm{a}} \\
\text { Proscription }\end{array}$ & $\begin{array}{l}\text { Revival } \\
\text { Maintenance } \\
\text { Interlingual Communicat. } \\
\text { International } \\
\text { Intranational } \\
\text { Spread }\end{array}$ \\
\hline $\begin{array}{l}\text { Acquisition planning } \\
\text { (about users of language) }\end{array}$ & $\begin{array}{l}\text { Group } \\
\text { Education/school } \\
\text { Literature } \\
\text { Religion } \\
\text { Mass media } \\
\text { Work }\end{array}$ & $\begin{array}{l}\text { Reacquisition } \\
\text { Maintenance } \\
\text { Foreign language/second } \\
\text { language } \\
\text { Shift }\end{array}$ \\
\hline $\begin{array}{l}\text { Corpus planning (about } \\
\text { language) }\end{array}$ & $\begin{array}{l}\text { Standardization } \\
\text { Corpus } \\
\text { Auxilliary code } \\
\text { Graphization }\end{array}$ & $\begin{array}{l}\text { Modernization } \\
\text { Lexical } \\
\text { Stylistic } \\
\text { Renovation } \\
\text { Purification } \\
\text { Reform } \\
\text { Stylistic simplification } \\
\text { Terminologyunification }\end{array}$ \\
\hline
\end{tabular}

The Hornberger 1994 integrative framework was based on Ferguson (1968), Kloss (1967), Steward (1968), Neustupny (1974), Haugen (1983), Nahir (1984), and Cooper (1989)

a I have proposed the additional language planning goals marked in the table, as observed in the Indian example and described in this paper 
goal of legitimization which encompasses the language planning acts of rationalization and classification described above. Allowing a spoken variety to be named as a language makes it legitimate-a language planning act that falls short of the active promotion of the language as through officialization or nationalization. Similarly not naming a language as legitimate is less restrictive than active proscription of the language as are the additional goals of protection and minimization described below.

Political motivations behind the legitimization of language can be found in the Indian context as in other countries. Khubchandani (2001) mentions the denial of the rights of linguistic minorities through use of the broad definition of mother tongue. Similar is the highly politicized question of whether Hindi, Urdu, and Hindustani are one, two, or three languages (2001). Daswani (2001) makes reference to the impact of one's affiliation and purposes on presentations of the number of languages in India. For example, as the first prime minister of India, Jawaharlal Nehru had an interest in promoting the unity of the Indian people. He said:

The notion that India has hundreds of languages is, like most other notions about her, entirely based on the lively imagination of some persons and has no basis in fact. India has a dozen languages, one of which - Hindustani - is spoken by about a third of her entire population and is understood by a great part of the rest. (quoted in King 1997: 3)

Later he called the notion of many languages ".... fiction of the philologist's and the census commissioner's mind" (1997: 4). However, Nehru was concerned for the protection of linguistic minorities, promoting Hindustani, with its inclusion of Urdu, over Hindi alone in the composing of the Constitution, and opposing the division of the country along linguistic lines. According to Agnihotri (2007: 187):

Nehru strongly believed that the division must take into account not only language but also geography, history and culture. He was also deeply aware of the presence of linguistic minorities in each territorial area and the fact that the presence of one dominant language, which would inevitably receive state support in a consensual democracy framework, would cause minority languages to suffer.

Some of the language-related debates that went on during the composing of the Constitution by the Constituent Assembly in 1946 are discussed in Agnihotri (2007), highlighting the complexity and politics in these language planning decisions.

When a group of spoken varieties are classified together under a single linguistic label, some diversity is minimized or ignored, resulting in the invisibilization of many linguistic varieties. Mahapatra (1986) points to minimization of minority languages, saying that "the government through its language census has also vastly increased the figure of scheduled languages to 95 percent of the total population in India and thus relegated the non-scheduled language speakers to a mere 5 percent" (208), an observation mentioned also by Khubchandani (2001: 8). The process of rationalization and the use of a broad definition of mother tongue help to explain 
how this happens. Planning for the status of a language begins with acknowledging its existence. However, sometimes it may seem expedient to ignore or minimize linguistic differences for the sake of group unity. Minimization of language status through denial of diversity reflects political motivations and ideological assumptions. This minimization of minority languages, or refusal to legitimize, is even more covert than legitimization in the census example and could also be considered a status policy goal. Perhaps minimization is the converse of legitimization and could be listed just above proscription in a continuum from restrictive to nonrestrictive policies (see Table 2).

What about Kumauni in relation to the counting of languages? Through the rationalization of mother tongues in the census, Kumauni becomes one of over fifty linguistic varieties that are classified under Hindi. Though they acknowledge the linguistic uniqueness of Kumauni, this categorization under Hindi seems quite natural to the Kumaunis with whom I spoke. Many Kumauni people report that Hindi is their mother tongue even if Kumauni is the language spoken in the home, including a professor who writes in and about Kumauni as a language. He said that this is a technical problem in the census. Since Kumauni has not found a place in the Indian Constitution, it comes under the area of Hindi. His assertion was that, however many Hindi boli [spoken varieties] there are, they are all considered dialects of Hindi. This professor does not question the situation, but sees a potential for change, saying: "When Kumauni gets a Constitutional position, then it will be counted. In the census it is a set form. If someone is from the Punjab, they list Punjabi; or if they are Muslim, they list Urdu. Otherwise, they list Hindi." This quote oversimplifies the situation, however, since I also met Punjabi-speaking Punjabis who insisted on listing Hindi as mother tongue for census purposes (Groff 2010).

While Hindi is often listed as the mother tongue of Kumaunis, Kumauni is usually the language spoken in the home, particularly in rural areas, and is known to be quite distinct from Hindi. This ambiguity is often explained as follows: "Kumauni is not a bhasha [language]. It is a boli [spoken language]," my informants would say. Boli is usually translated as "dialect." I explore this distinction as it is used among Kumaunis in Groff (2010, 2013). For official purposes, and likely following the discourses learned at school, most rural Kumaunis seem willing to accept their spoken variety as not having the status of a language and maybe not even as mother tongue. The District Education Officer of Bageshwar, in talking about the Census, said that here the language is listed not as Kumauni but as Hindi because Hindi is the reading/studying medium. The fluid linguistic reality of boli is reflected in a popular saying about the variety in spoken language: "Every mile the water changes; every four miles the speech." Kumauni does indeed vary from village to village and region to region, and many scholars identify at least fourteen dialects (Bisht 2005; Sharma 1988, 1994). More easy to relegate to the census is the standard, discrete, countable entity of bhasha, a language that is written and used for schooling.

When I raised questions about the status of Kumauni and the difference between bhasha and boli, responses included reference to the form of the variety (whether or not Kumauni was developed or standardized enough to be a language), its function 
(whether it is written and/or "used" as a language), and its official status (what the government calls it). I was often given an explanation about the fact that Kumauni is not yet recognized as a language by the Indian government-or, more specifically, that Kumauni has not been listed in the nation's Constitution (Groff 2010). One of the proposals raised at a seminar on Kumauni language held in Kausani was that, when giving their language to the Census, everyone should write Kumauni instead of Hindi. This had been, we were told, an important part of the movement for getting the Santhali language recognized in the Constitution. The following section discusses the more explicit status planning recorded in the Indian Constitution.

\section{Which languages get status? Status planning through officialization}

During India's move towards independence, the question of which language to use for official purposes in the new nation sparked much discussion, which is not surprising in light of the nation's vast linguistic diversity. Continuing the use of English for official purposes was one option and many colonized nations have chosen such a route at independence. Such a policy would maintain efficiency in the systems that were already in place and, most importantly, would not promote the dominance of one Indian language group over another.

Many Indian leaders, including Mahatma Gandhi, felt strongly, however, that the use of a foreign language would not be appropriate. His requirements for a national language are listed as follows:

1. It should be easy to learn for government officials.

2. It should be capable of serving as a medium of religious, economic, and political intercourse throughout India.

3. It should be the speech of the majority of the inhabitants of India.

4. It should be easy to learn for the whole of the country.

5. In choosing this language, considerations of temporary or passing interests should not count. (Das Gupta 1970: 109, quoted in Baldridge 2002)

The language that Gandhi promoted was Hindustani, encompassing both Hindi and Urdu, significant because of the religious tensions between Hindus and Muslims. After the partition of India and Pakistan, however, Hindi took precedence in India since Urdu was associated with Muslims and Pakistan.

The Constitution of India of January 26, 1950, needing to maintain unity within diversity, addresses the language issue more explicitly than most other national constitutions. The official language of the new nation was declared in Articles 343-344 to be Hindi, written in the Devanagari script, with English as an auxiliary official language whose status was to be reconsidered in 15 years. Concerning the states, the Constitution allows for choice of official language, an important concession that was demanded particularly in non-Hindi-speaking states. Article 345 states that 
the Legislature of a State may by law adopt any one or more of the languages in use in the State or Hindi as the language or languages to be used for all or any of the official purposes of that State: Provided that, until the Legislature of the State otherwise provides by law, the English language shall continue to be used for those official purposes within the State for which it was being used immediately before the commencement of this Constitution. (Constitution of India)

Also included in Articles 346-349 are provisions for language use in the Supreme Court and High Courts and for communication between states and with the central government. The Constitution also established the right of the Indian president to recognize a regional language should s/he observe that this is needed and wanted by a significant portion of a state's population.

The means used in the Constitution for recognizing the regional languages is through their listing in the Eighth Schedule of the Constitution. The Eighth Schedule's original purpose was stated in Article 351 in relation to the corpus planning of Hindi:

It shall be the duty of the Union to promote the spread of the Hindi language, to develop it so that it may serve as a medium of expression for all the elements of the composite culture of India and to secure its enrichment by assimilating without interfering with its genius, the forms, style and expressions used in Hindustani and in the other languages of India specified in the Eighth Schedule, and by drawing, wherever necessary or desirable, for its vocabulary, primarily on Sanskrit and secondarily on other languages. (Constitution of India)

As Mahapatra says: "It is generally believed that the significance for the Eighth Schedule lies in providing a list of languages from which Hindi is directed to draw the appropriate forms, style and expressions for its enrichment" (1986: 206; see also Khubchandani 2001: 14). Being recognized in the Constitution, however, has had significant relevance for a language's status and functions. This provides an example of the same act serving both corpus and status planning purposes.

The fourteen languages first listed in the Eighth Schedule of the Constitution were Assamese, Bengali, Gujarati, Hindi, Kannada, Kashmiri, Malayalam, Marathi, Oriya, Punjabi, Sanskrit, Tamil, Telugu and Urdu. Through the 21st Amendment in 1967, Sindhi was added to the list, and in 1992 the 71st Amendment brought the total to eighteen with the addition of Nepali, Manipuri, and Konkani. In 2003, the 100th Constitutional Amendment added Bodo, Santali, Maithili, and Dogri to the list of scheduled languages, bringing the number of scheduled languages in India up to twenty-two. Movements by minoritized language groups have been and are underway in a push for constitutional recognition, but as one Indian prime minister implied in discussing this issue, if one language is included, then 200 others could be included (cited in Mahapatra 1986: 207).

State Official Language Acts were passed in the various states between 1950 and 1987. Though implementation varies by state, most states have formed advisory committees and organizations for the development of the regional language for use 
in official domains. Jayaram and Rajyashree (2000: 26) observe that "in almost all the states, initial enthusiasm died and indifference prevailed soon which led to amendments in the Official Language Act providing continuance of English for most of the official purposes..." They also mention how provisions for minority languages vary from state to state.

Kumauni has not been recognized among the scheduled languages in the Indian Constitution. However, it was recognized by the state of Uttar Pradesh and by India's University Grants Commission (UGC), and since 1990 has been taught as a subject at Kumaun University (Bailey et al. 1999). Some efforts are being made to gain official recognition for the Kumauni language at the national level, including the organization of conferences and sending of petitions. However, I found little awareness of these initiatives in the rural context. As mentioned above, one of the reasons mentioned for why Kumauni is only a spoken variety or boli as opposed to a language or bhasha, and why it is often deemed unfit for educational purposes, is the fact that it is not recognized by the national government. Although it is not a forefront concern for most of my informants and seems improbable to many, recognition of Kumauni would be seen by them in a positive light.

\section{What about the other languages? Language rights and minority safeguards}

Although twenty-two languages are recognized or scheduled in the Indian Constitution, many other languages and/or linguistic varieties remain unrecognized. Addressing such language groups, the Constitution of India includes certain safeguards to protect linguistic minorities from the prohibition of their languages and from some discrimination. This explicit acknowledgment of linguistic rights is rare in other national Constitutions. Given the great diversity within India, some assurance was needed in its uniting under a democratic government that the rights of all peoples would be protected. Article 29 of the Constitution of India provides explicit guarantees for protecting the interests of minorities:

(1) Any section of the citizens residing in the territory of India or any part thereof having a distinct language, script or culture of its own shall have the right to conserve the same.

(2) No citizen shall be denied admission into any educational institution maintained by the State or receiving aid out of State funds on grounds only of religion, race, caste, language or any of them.

Having stated the right of minority peoples to maintain their own language and culture, the Constitution adds on the explicit protection of the rights of minorities to provide their own education in their own language, certainly an important part of language maintenance. Article 30 details this right along with protection against discrimination in the receiving of government grants for education:

(1) All minorities, whether based on religion or language, shall have the right

to establish and administer educational institutions of their choice. 
(1A)...The State shall not, in granting aid to educational institutions, discriminate against any educational institution on the ground that it is under the management of a minority, whether based on religion or language.

While not explicitly planning for the status of particular languages, these Constitutional safeguards provide protection for language maintenance objectives. Giving languages the right to be and the right to be learned through protection seems also to be an implicit form of status planning, related inversely with prohibition (see Table 2).

Besides these general safeguards, the Indian Constitution includes a section titled Special Directives, where language and education issues beyond simple protection for minorities are explicitly addressed. Article 350 guarantees the right of all people to use a language they understand in "representations for redress of grievances." In the Seventh Amendment to the Constitution made by the Constitution Act of 1956, two articles were added that go far beyond most national Constitutions in addressing linguistic minority issues:

350A. Facilities for instruction in mother-tongue at primary stage.

It shall be the endeavour of every State and of every local authority within the State to provide adequate facilities for instruction in the mother-tongue at the primary stage of education to children belonging to linguistic minority groups; and the President may issue such directions to any State as he considers necessary or proper for securing the provision of such facilities.

The following article establishes a special officer for linguistic minorities to investigate and report on the implementation of these minority safeguards. While the definition of linguistic minorities was not included in the Constitution, a Supreme Court decision defined minority languages as separate spoken languages, not restricted to languages using or having a separate script (Dua 1986: 134).

The framers of the Constitution recognized the importance of addressing "the problem of the minorities," a universal issue in democracies, and they "had a firm faith that healthy national consciousness would grow if the minorities are guaranteed liberty, equality, fraternity and justice" (Kumar 1985: 9). This protection of minorities by the government stands in contrast to the minimization of languages described in the context of the Indian census above. While it may have seemed in the government's interest to smooth over the linguistic diversity in search of unity, the rights of the vocal minorities needed to be addressed. Safeguarding those rights was an important political issue at independence. Elsewhere in the Indian Constitution, scheduled castes and scheduled tribes are listed as minority groups requiring special protection. Although the Constitution provides no explicit acquisition planning for minority languages, the protection of minority rights provides space for the use and teaching of those languages.

In the Kumauni context, many Kumaunis rose up to join the Indian nation in the struggle for independence. Likewise, Kumaunis joined with their neighboring Garhwalis to demand the separate mountain state of Uttarakhand, established in 2000. However, these have not been the language-related struggles seen in other Indian states. Official mother-tongue education in Kumauni has not been demanded 
and is not generally considered to be an option. Government-school instruction is officially in Hindi, and in educational contexts in particular, Hindi is usually considered to be the mother tongue. Yet, I have found that rural Kumaunis value the Kumauni language within its role as the language of the home and local community (Groff 2010).

\section{What languages in education? Indian education policy, status and acquisition planning}

According to Cooper (1989: 109), choice of media of instruction for school systems "is perhaps the status-planning decision most frequently made, the one most commonly subject to strong political pressures." Often decisions are based more on political considerations than on concern for facilitating education (1989). India's complex linguistic situation adds complexity to education decisions regarding languages to use as media of instruction and languages to be taught as subjects. Both are important for acquisition planning, with its emphasis on planning for the teaching and learning of language(s), under which Hornberger (1994) categorizes the educational function of language.

\section{A brief history of language-in-education planning in India}

Prestige languages used in India for educational purposes over the generations included Sanskrit (codified since 500 BC), Persian (under the Mughal dynasty which ruled with varying strength from the 16th to the 19th century), and English (under the British East India Company from the 17th to the 19th century and under the British Raj from 1858 to 1947). Throughout India's recent history the question of medium of education has raised significant debate. During British rule there was debate about whether and when to use the vernacular as opposed to English in education, including Orientalist versus Anglicist perspectives. Appendix 1 outlines the major colonial decisions concerning language, education, and linguistic minorities.

In the infamous Minute of 1835, T. B. Macaulay, Chairman of the General Committee on Public Instruction, proclaimed the superiority of English as medium of instruction:

We have to educate a people who cannot at present be educated by means of their mother-tongue. We must teach them some foreign language. The claims of our own language it is hardly necessary to recapitulate. It stands preeminent even amongst the languages of the West. (Sharp 1920, quoted in Sharma 1985: 2)

Still, during colonial rule some Indian languages did came into use in education as a transitional medium to pacify the people's demands, and national leaders in the drive for independence spoke for universal primary education through Indian languages. The language issue was so powerful, in fact, that questions about content in education were pushed into the background. The strength of Gandhi's opinion is 
clear as he opposes the colonial domination represented by the English language: "The foreign medium has made our children practically foreigners in their own land. It is the greatest tragedy of the existing system. The foreign medium has prevented the growth of our vernaculars" (Gandhi, M. Education. Ministry of Education pp. 15-16, quoted in Sharma 1985: 13). Gandhi saw the connection between educational status and the corpus planning of a language, rejecting the idea that languages must first be developed before they can be used in education. Challenging Macaulay's ideas about the superiority of English, Gandhi expressed his opinion about the use of English as the national language as follows:

Our language is the reflection of ourselves and if you tell me that our languages are too poor to express the best thought, then I say that the sooner we are wiped out of existence, the better for us. Is there a man who dreams that English can ever become the national language of India? (Cries of 'Never'). (1916, quoted in Saksena 1972: 28)

After independence in 1947, language-in-education decisions were not simple given the demands of the diverse inhabitants of the states and diverse opinions throughout the new nation. Commissions and committees were appointed to address language and education issues. Appendix 2 outlines key historical decisions by the Indian nation concerning language, education, and linguistic minorities up to the revisions of the Three-Language Formula, described below. In principle, many policies promoted the use of minority languages. Provincial governments were not to force minorities into linguistic conformity; however, at the same time, the voices of minorities often went unheard (Ekbote 1984). More recently, the 2005 National Curriculum Framework (NCERT 2005) makes a clear statement regarding the importance of providing mother tongue education for all.

While many policy advances have been made regarding the use of minority languages in education, most of the national decisions may be seen only as suggestions given the fact that education, for the most part, comes under the jurisdiction of the states. The role of the national government comes in uniting the support of the states, coordinating higher education institutions, persuading the elite of the importance of a particular scheme, and providing financial incentives for specific programs (Khubchandani 2001). The central government "does not exercise any effective control over the implementation of general education programmes" (Khubchandani 1981: 6). Still, national decisions regarding education do influence the decisions of states, as exemplified in the Three-Language Formula.

\section{The Three-Language Formula: acquisition planning for recognized languages}

The Three-Language Formula, first presented in 1956 by the Central Advisory Board of Education, deals with acquisition planning through the selection not of media of instruction but of languages to be taught as school subjects. While the minority languages receiving attention in this article are not included among languages to be taught and my discussion of it here is necessarily brief, the formula 
certainly influences the education of linguistic minorities. The Three-Language Formula includes the following (according to the 1966 modifications):

1st the mother tongue or regional language, to be taught for 10 years

2nd the official language-Hindi or English, to be taught for 6 years, minimum

3rd another modern Indian or foreign language, to be taught for 3 years, minimum

The language first used depends on the definition of mother tongue. The choice of second and third language is, according to Khubchandani "tied up with the issues of language privileges, cultural prestige, and socio-economic mobility" (1981: 14). The multilingualism promoted in the Three-Language Formula springs in part from a concern for maintaining the status of the official and regional languages, and for ensuring that Indians from various regions would learn one another's languages. Concern continues in India for the maintenance and spread of the official Indian languages. This includes a concern that the spread of English and the increasing demand for English-medium education threatens the acquisition of Indian languages.

While overall a broad consensus exists among states, implementation of the Three-Language Formula varies considerably. According to Ekbote (1984), difficulty in the implementation of the Three-Language Formula comes from the following factors: (a) the "heavy language load in the school curriculum," (b) northern schools not being motivated to teach south Indian language, (c) southern schools, especially in Tamil Nadu, resisting the teaching of Hindi, and (d) the cost of arranging for instruction. The formula has been adapted by the various states with some teaching only two languages, some needing four, and some providing additional optional languages. Even when implemented as intended, the formula has been said to have lost its symbolic value, becoming merely an examination ritual (Annamalai 2001). For a summary of current implementation and lists of languages taught in the various states, see Meganathan (2011).

With respect to the speakers of minority languages, critiques of the ThreeLanguage Formula emphasize its failure to distinguish between regional languages and mother tongues, thus ignoring the situation of minorities whose mother tongue is not the regional language. Under the Three-Language Formula, those students whose mother tongue is not an official or regional language end up learning four languages, and possibly three or four scripts, since they come to school with a language different from the first language of instruction. The policy has been referred to as 3 plus or minus one since Hindi speakers need only learn two languages and minority-language speakers require four (Ager 2001: 29). While knowing four languages should certainly not be thought of as a disadvantage, children who are educated through the medium of an unfamiliar language face greater learning challenges than their peers (Jhingran 2005).

In the Kumaun, the three languages offered in government schools are Hindi, English, and Sanskrit. Since 2004, the teaching of English has started from Class 1 (first grade) rather than Class 3. Both English and Sanskrit are compulsory up until Class 8, after which there is a choice between either English or Sanskrit. The third 
language in the Three-Language Formula was intended to be a "modern Indian language," but Sanskrit, as one of the 22 scheduled languages, provides a loop-hole, serving as the third language in much of Hindi-speaking North India. During my fieldwork, I heard hints of a debate about introducing Kumauni (and Garhwali) as school subjects in Uttarakhand, but this prospect did not reach the state policy level until 2014. Most Kumaunis instead place a high priority on the learning of English. Sanskrit is learned, they say, because it is the root or origin of our language. Hindi also is valued as "our national language," and I heard criticisms raised about south Indians who are reluctant to learn Hindi (Groff 2010).

\section{Medium of instruction and minority rights: use of minority languages in education}

When it comes to medium of instruction, the Indian Constitution and national educational policies tend to favor mother-tongue-medium instruction. Proponents of multilingual education considered a success the 2005 National Curriculum Framework (NCERT 2005) with its statements on the importance of providing mother tongue education for all. The pluralistic provisions safeguarding the rights of linguistic minorities in the Indian Constitution and in education policies exceed those of many nations, as, for example, in the United States where the Constitution provides no guarantee of language rights or educational rights related to language. Another recent addition to these policies promoting mother-tongue instruction came in July 2009 with the passing in both Houses of Parliament of the Right of Children to Free and Compulsory Education Bill (Rajya Sabha Bill No. LXV-C, 2009), which includes the provision that: "(f) medium of instructions shall, as far as practicable, be in child's mother tongue."

As Dua (1985: 172) pointed out, however, regarding national policies, "it depends on various socio-political and sociolinguistic factors whether or not these provisions are effectively implemented." Given the complexity of India's multilingual situation and "the variations in the size and concentration of linguistic minorities," while some minority languages are being used in education, mass media, and/or administration, "the implementation of constitutional safeguards is a challenging, stupendous task" (Dua 1986: 134-135). The Linguistic Survey of Tribal Dialects and Cultures, focusing on four districts of Orissa, reported that "India has failed to meet the commitment of universalizing Primary Education and ensuring a basic human right because of this problem of language" (Linguistic Survey 1999, cited in Pattanayak 2001, p. 52). The Report of the Group on Minorities Education, focused particularly on the Urdu-speaking minorities, also issued a negative report. The right of primary education in the mother tongue was being denied many Urdu speakers. They note the "alarming drop-out rate" of minority students and point out how the system was causing children to "suffer grievously at an impressionable age" (1991: 72). Their suggested solution mostly reflects a desire to see the current provisions fully implemented: 
Nothing short of instruction in the child's mother tongue at the elementary stage and inclusion of Urdu in the Three-Language-Formula at the secondary stage, can salvage the situation, remove the grievance of the minority and improve the quality of education and prospects of minority students. (1991, p. 72)

Yet in other situations, as for example in the Kumaun, there is little demand for official use of the home language in the school. At government schools in the Kumaun, Hindi is the default medium of instruction at all stages of education as both the dominant regional language and a pan-Indian language. Meanwhile, most private schools and the Central Government Schools (Kendriya Vidyalaye) established for government employees offer English-medium instruction.

Reasons for rejecting mother-tongue instruction include demand for higher-status languages for social and economic advance. From a look at educational preferences in India, the medium of instruction preferred by most from the primary stage onward is the one most valued at the higher stages of education: English. Those who can afford to do so send their children to English-medium schools, and the government also has begun in some schools to comply with this demand for English medium. Concerns continue for the promotion of India's official and regional languages, languages that themselves appear to be "minority" languages beside English. Much has been said about the role of English in Indian education, including the power of English on policy (Annamalai 2001) and implications of medium-ofinstruction policies for the less privileged in society (e.g., Ramanathan 2005a, b). Minoritized language groups, whose languages are one step less legitimized than the vernacular or regional languages, then face a "double divide" related to language in education (Mohanty 2010). Such hierarchical multilingualism contributes to a loss of diversity and to "educational failure, capability deprivation and poverty in the minority linguistic groups" (2010).

Reasons for demanding mother tongue education, on the other hand, include pedagogical and political motivations. Regardless of the global and political status of a child's mother tongue, educational research has shown that children learn best when taught in their own languages, and minority children in particular face multiple disadvantages when they are required to learn primary literacy skills through the medium of a second language (Jhingran 2005). The multilingual contribution from the state comes from its obligation to provide education and to keep children from dropping out of school (Annamalai 2001). As Annamalai points out, however, "the state may provide a place for the minority mother tongue in education not on any principle of pedagogy or human right but to meet political expediency" (2001:72). Regardless of the motivation behind them, such policies change the status of a language and contribute to its acquisition and maintenance.

In the Kumaun, what educational benefits might be gained from introducing or encouraging the home language, Kumauni, as medium of instruction in place of or alongside Hindi remains to be explored. However, from discussions with many teachers, I have learned that in rural areas Kumauni is often used informally in school for explaining concepts, particularly in the lower primary grades while 
children are learning Hindi (Groff 2010, 2013). These multilingual practices represent another layer of informal language planning in India, as discussed below.

\section{Implementation issues and multilingual classroom practices}

Reporting the number of languages used as media of instruction in India is reminiscent of the complexity addressed earlier of numbering the nation's languages. In 1976 there were reported to be 33 tribal languages in use as media of instruction in schools (Pattanayak 2001: 57). In 1981, Khubchandani (1981: 6) reported that a total of 80 languages were being used as media of instruction in India. In 2001, Annamalai reported 47 languages used as media of instruction, and Singh (2008) reported that there are 34 languages used in schools in India. Meanwhile, Jhingran (2005) states that less than 20 languages are being used for media of instruction in primary education. Several Indian states have implemented the use of minority languages as "preparatory medium" or "partial medium" (Khubchandani 2001: 32). Besides state provisions, some tribal schools have been formed by the national Education Department and some by the Welfare Department, while other mother-tongue education programs have been promoted by NGOs.

Even when mother-tongue education policies and programs are initiated, implementation problems often hinder the use of minority languages in education. Program implementation suffers from inefficiencies due to few inspections, absent teachers, unavailability of texts, and alienation from the home language (Pattanayak 2001). According to Dua (1985), the use of minority languages in education faces implementation problems, not due to lack of student motivation and ability or from the parents' devaluation of such instruction, but from pedagogic, environmental and curricular problems. The use of tribal languages in the first few years of education is not an automatic solution to educational problems for linguistic minorities. As Pattanayak (2001: 54) says: "With inexperienced teachers and insufficient reading materials these programs are apologies for education." Contributing to the problem are literacy materials with very little practical village content and little that would be motivational for learners, as well as the lack of planning for transitions from one language to another in the school (2001). Other hindrances to program implementation spring from mistrust, as some administrators fear more demands from minority groups and community members fear loss of access to the languages of power (Annamalai 1990). Annamalai points out that bilingual education faces more resistance when it is centrally planned than when it is used informally, a part of the multilingualism common in society.

Although this historical account has highlighted multiple challenges, mothertongue education for linguistically minoritized groups boasts some success stories in recent years. Currently several states, including Andhra Pradesh, Odisha (formerly Orissa), and Chhattisgarh, are giving attention to mother tongue instruction for tribal minorities, sometimes in collaboration with NGOs. The motivation is primarily to provide adequate educational support to populations that have experienced high rates of educational failure and drop-out. Such tribal minorities are considered quite distinct from the speakers of so-called dialects of Hindi or other regional languages. 
Evaluations of these programs report numerous positive outcomes for the use of mother tongue beyond academic performance (e.g., NCERT 2011).

Looking beyond program implementation to micro-level decisions about language use in the classroom reveals another layer of language planning in India. The multilingualism that has been observed in educational settings in India outside of official policy deserves some consideration. Khubchandani (1981) notes that "in actual practice one notices a good deal of code-switching and hybridization of two or more contact languages in informal teaching settings" (31). Multilingual teachers can adapt to the needs of their students, and various forms of multilingualism become evident in the Indian classroom. According to Khubchandani (2001),

it is not unusual to find in many institutions anomalous patterns of communication where the teacher and the taught interact in one language, classes are conducted in another, textbooks are written in a third, and answers are given in a fourth language or style. (33)

He also points out the importance of respect for grassroots 'folk' multilingualism, building on his earlier statement that "in the 'filterdown-approach of the educational elite, grassroots 'folk' multilingualism is devalued" (1992: 102). According to Khubchandani (2001) and Annamalai (2001), multilingual practices in the classroom, though unofficial, may play an important role in transitioning students from one medium of instruction to another, resulting in what Annamalai calls "unplanned simultaneous bilingual education" (2). Annamalai (1990) differentiates natural bilingualism and planned bilingualism, as Groff (2013) differentiates official and unofficial media of instruction. In a multilingual setting, such informal multilingual practices come naturally (see Pattanayak 2001).

Agnihotri (2007) has suggested a more structured way of using multilingual resources in instruction, building on the linguistic resources of the students and allowing them to use the language they know best in building their understanding. He says:

Any classroom in India is in general multilingual, and unless we conceptualize the school curriculum, syllabus, textbooks and classroom transaction in terms of multilingualism as a resource, strategy and a goal, where languages are not seen as discrete objects and language boundaries are porous, we may not be able to arrive at a pedagogical breakthrough where an individual child's language and systems of knowledge are respected. (Agnihotri 2007, p. 197)

Such an approach reflects current conversations about the use of pluralingual forms of communication in education, whether labelled translanguaging, transliteracy, plural language practices, or polylingual languaging (Baker 2003; Creese and Martin 2003; García and Wei 2014; Jørgensen 2008). Whether natural de facto multilingual education can provide an effective bridge between access to education through the mother tongue and access to higher education and economic advancement though the more powerful languages remains to be seen. This question too is not without its controversies, and India's multilingual classroom practices deserve further exploration. 
Taking a final look at the Kumauni context, the multilingualism in the Kumaun can be seen reflected in unofficial multilingual classroom practices. During my fieldwork, preschool and primary school teachers would often admit to me that they use Kumauni to help children bridge to Hindi in rural areas, though they considered this practice undesirable, reflecting low-quality education. Kumauni thus serves as an "unofficial medium of instruction" (Groff 2010, 2013). Similarly, I observed extensive use of Hindi and the mixing of both English and Hindi in English-language classrooms and at "English-medium" schools. I have proposed that "rather than feeling ashamed of these multilingual practices, teachers could learn to build more systematically on the multilingual resources in their classrooms, tapping into the benefits of mother-tongue instruction and encouraging their students in the multilingual competencies needed in a multilingual world" (2013: 204).

\section{Conclusions: Legitimization in perspective}

Through this analysis of India's linguistic diversity from a language planning perspective, several questions have been raised, the answers to which are colored by ideological and spatial perspectives. How many languages are there in India? This is a question open to debate-a question involving definitions, census practices, and multiple motivations. Which languages get status? What about the other languages? Though addressed in the Constitution, issues of explicit language status are also contested, and the reasons for recognizing languages are rarely linguistic. What happens in education for linguistic minorities? Constitutional rights and national education policies make some provision, but implementation varies. And what actually happens in the classroom adds another level of complexity deserving more exploration.

National-level approaches to counting, recognizing, and educationally promoting languages are described here with an intentional emphasis on minoritized languages and the implications of such language planning from community-level perspectives. Through the Indian example, I have proposed the additional language planning goals of legitimization (including processes like classification and rationalization), protection, and minimization. National-level language and language-in-education planning in India, whether implicitly or explicitly, fails to legitimize many minority languages, minimizing some of the nation's rich diversity. Meanwhile, safeguarding the rights of linguistic minorities in the Constitution represents the goal of language protection as opposed to proscription. The contrast between the implicit minimization of minority languages and their explicit protection in the Constitution is also worth further analysis. Throughout India's history as a nation, the government has in various ways addressed the linguistic diversity in India, with complexity and controversy at each turn. The motto of "Unity in Diversity" has been cited often in India, where diversity in its various forms cannot be ignored. Textbooks pick up the theme and emphasize the unity within the diverse Indian nation (Rajagopalan 2001). On the ground in the 
Kumaun, in the analysis of some locals, unity is most important: "The more we ignore differences, the more developed we become." Most often, however, diversity was not presented as a barrier to unity: "In their own place each [language] is important." Although the nation of India has united a great deal more diversity than most nations, the emphasis of unity over diversity seems also to vary depending on the context and depending on the perspective taken.

In whose interest is an emphasis on unity over diversity? Who is served when India is said to have certain numbers of languages and when certain languages are considered more legitimate than others? What are the consequences for the educational opportunities of linguistic minorities? Such questions are unfortunately rarely central to national-level language policy and planning decisions. Language ideologies legitimize the power dynamics favoring some perspectives over others, some linguistic varieties over others, some forms of linguistic practice over others, and some forms of linguistic categorization over others. In most of the above descriptions, I have implied that more of India's linguistic varieties should be legitimized, counted as languages, given the status they deserve and promoted in education. I imply that the protection of a language not only negates proscription but also renounces the minimization of a linguistic variety and its speakers. Yet in so doing I legitimize linguistic categories, suggesting the countability and controllability of linguistic varieties. Thus, I now raise for myself the question of whose interests are served through such an analysis. A subtle acceptance of monoglossic ideologies of bilingualism, which separates languages into autonomous systems (García 2009), can fog one's vision. Only in the final sections do I explicitly acknowledge the pluralistic language practices that defy linguistic categorization.

The Kumauni case provides a local perspective on Indian language planning. For its two million speakers, Kumauni counts. Yet the minimization of Kumauni through census procedures and lack of constitutional recognition does influence local discourses and language practices, especially in educational contexts. The push-back comes through local ideologies that allow for multiple linguistic varieties, multiple identities, and unofficial media of instruction. The impact of national-level policies is evident in the Kumaun and yet the local ideological environment allows for the valuing of linguistic diversity and provides a legitimate place for each linguistic variety. At the classroom level, ideological space for multilingualism provides some implementational space not afforded in official policy (Hornberger 2002; Groff, forthcoming). Though the on-the-ground realities in the Kumaun are influenced by national-level language and education policies, local language ideologies in some ways trump such policies, allowing space for multilingual practice.

\section{Compliance with ethical standards}

Ethical approval The ethnographic research presented here, involving interaction and interviews with human participants, was conducted according to the ethical standards of and with approval from the University of Pennsylvania's Institutional Review Board (Protocol \#806419). 
Open Access This article is distributed under the terms of the Creative Commons Attribution 4.0 International License (http://creativecommons.org/licenses/by/4.0/), which permits unrestricted use, distribution, and reproduction in any medium, provided you give appropriate credit to the original author(s) and the source, provide a link to the Creative Commons license, and indicate if changes were made.

\section{Appendix 1: History of colonial language-in-education planning in India (compiled from Dua 1986; Khubchandani 1981, 2001; Sharma 1985; Daswani 2001; Ekbote 1984)}

1797-Charles Grant of the East India Company discussed possibilities for educating Indians.

1813-The 1813 Charter of the E.I. Company, allocated 100,000 Rs. to educate Indians through an Indian language.

1833 - The 1833 Charter allocated 1,000,000 Rs. to educate Indians.

1835-Macaulay's famous Minute of 1835-T.B. Macaulay, Chairman of the General Committee on Public Instruction proclaimed the superiority of English for use in Indian education, i.e., education to a minority, given the need for development of the Indian languages:

We have to educate a people who cannot at present be educated by means of their mother-tongue. We must teach them some foreign language. The claims of our own language it is hardly necessary to recapitulate. It stands preeminent even amongst the languages of the West

(Sharp, H. Selections from Educational Records, Part I 1781-1839, p. 110, In Sharma 1985: 2)

-That same year a resolution was passed approving Macaulay's suggestion.

1854-The Wood's Dispatch reaffirmed the importance of English in education but promoted the use of the vernacular at the school level for those not knowing English.

1882 - The Hunter Commission also suggested the use of vernacular in primary education for subjects not leading to university study.

1904-A Resolution on Educational Policy by the (colonial) Government of India suggested the age of thirteen as a point of division for use of vernacular versus English in education.

1913-A Resolution on Educational Policy called for improvement of English at the secondary level.

1915-Rama Rayaningar's Motion in the Imperial Legislative Assembly for the use of vernacular in secondary school with instruction on English as a second language sparked debate in parliament but brought no resolution, the decision being left to the states:

It was also openly admitted that a boy receiving education through the vernacular medium up to the highest classes of the school had an edge over the boy educated in English through middle school because he did not have the disadvantage of studying through a foreign language (Sharma 1985: 3). 
1929-The Hartog Committee suggested the use of bilingual instruction in one school instead of starting two schools with different media in the same area. The Committee didn't specifically examine vernacular languages or media of instruction, however.

1931-The Indian National Congress passed the "Karachi rights" declaring protection for the "culture, language and scripts of the minorities and of the different linguistic areas"

1937-The Wardha Education Scheme recommended 7 years of basic education for all under the influence of Gandhi, who strongly opposed the use of a foreign language.

1937- The Abbott-Wood Report recommended the use of vernacular in high school, with English also compulsory.

1938 - The Committee of Central Advisory Board of Education advocated the use of the mother-tongue in primary education to be supported by the government. At the Annual Meeting of the Central Advisory Board, however, it was said that dialects were clearly not acceptable as media of instruction.

\section{Appendix 2: Post-independence language-in-education planning in India and history of the 3-Language Formula (compiled from Dua 1986; Khubchandani 1981, 2001; Sharma 1985; Daswani 2001, Ekbote 1984)}

1947-An Expert Committee of the Indian National Congress made recommendation for the protection of minorities who would not be kept from developing their languages, but also for government support in providing facilities for mother-tongue education if a non-regional language is used by a significant proportion of the population.

- The Minorities subcommittee of the Central Advisory Board of Education made a similar recommendation for rights protection.

1948 - The National Planning Committee on General Education and Technical Education and Developmental Research reported that the time and energy of the students were diverted by the use of English and that the mother-tongue should be used at the secondary level.

1949-The Central Advisory Board of Education and the State Education Ministers' Conference stated that at the primary stage mother-tongue instruction should be provided for linguistic minorities with 40 or more students in a school or 10 in a class. The regional language would be introduced after Class 3. Secondary education in the mother tongue would also be provided given sufficient numbers of students. It was stated that "the medium of instruction in the junior basic stage must be the mother-tongue of the child and that when the mother-tongue was different from the regional or State language arrangements must be made for instruction in the mother tongue by appointing at least one teacher to teach all the classes, provided there are at-least 40 such pupils in a school" (Ekbote 1984, pp. 200-201)

- The Congress Working Committee issued a resolution on bilingual areas, revealing a language-as-problem orientation. Provinces would choose a language for administration and education. In bilingual areas where a minority group made up 
more than $20 \%$ of the population, public documents should be available in both languages. State languages for communication with provinces and union government would replace English in 15 years.

- The University Education Commission, however, stated that only modern literary languages were fit for instruction.

1952 - The Secondary Education Commission suggested a Two Language Formula.

1953-The All-India Language Development Conference decided that tribal languages were acceptable media for primary schools.

1954-The Congress Working Committee agreed that the use of tribal languages was acceptable in primary schools.

1956 - The Central Advisory Board of Education suggested the Three-Language Formula.

- Protection for mother tongue education would still be possible up to the secondary level.

- The Second Five-Year Plan included provision for making textbooks in minority languages.

-On a different note, the Official Language Commission stated that only modern literary languages were fit for instruction, demonstrating that diversity of opinions still prevailed.

1961-The Conference of Chief Ministers of various states approved a simplified Three-Language Formula with the purpose to "promote national integration and equalise the burden of learning languages on children in Hindi and non-Hindi speaking areas" (Kumar 1985). The language to be added in secondary school was to be a modern Indian language, and thus, most notably, languages of the southern states should also be taught in the north.

-On a different note again, the President of India stated that it was not reasonable to expect mother tongue instruction to be provided for small linguistic minorities.

1964-1966-The Education Commission "emphasized the role of mother tongue education for the massive resurgence of national life, the development of indigenous languages, the achievement of industrialization and modernization goals through a wider dissemination of science and scientific outlook and the release of original, creative thinking necessary for national development" (Dua 1986, p. 166).

1966-The Education Commission issued a Modified 3-Language Formula:

1st the mother tongue or regional language would be taught for 10 years

2nd an official language-Hindi or English-would be taught for 6 years minimum, to be introduced in 5th-7th grade

3rd another modern Indian or foreign language would be taught for 3 years minimum, to be introduced in 8th-10th grade

1968 - A Resolution of Parliament on the Official Language Policy affirmed the importance of the Three-Language Formula for learning other regional official Indian languages.

1968-The National Policy on Education urged implementation of the ThreeLanguage Formula. 
1979-The National Policy on Education (Draft) affirmed that "the medium of instruction at all stages shall be the regional language except a the primary stage where it will be the mother-tongue."

1986-The National Policy on Education, paragraph 4.8 states:

Some minority groups are educationally deprived or backward. Greater attention will be paid to the education of these groups in the interest of equality and social justice. This will naturally include the constitutional guarantees given to them to establish and administer their own educational institutions, and protection to their languages and culture. Simultaneously, objectivity will be reflected in the preparation of text books and in all school activities, and all possible measure will be taken to promote an integration based on appreciation of common national goals and ideals, in conformity with the core curriculum

(quoted in Group on Minorities Education 1991: 76)

This provision under the section on scheduled tribes, was not addressed as an issue of language or titled bilingual education, but was introduced as follows: "The socio-cultural milieu of the scheduled tribes has its distinctive characteristics including, in many cases, their own spoken languages. This underlines the need to develop the curricula and devise instructional materials in the tribal languages at the initial stages, with arrangements for switching over to the regional language" (quoted in Annamalai 1990: 2). Primers were to be prepared for tribal languages with over 100,000 speakers by the end of 1990 .

1992 - The National Policy on Education issued another revision of the ThreeLanguage Formula. Up to the present the Indian Parliament remains busy on the theme of language in education.

\section{References}

Ager, D. (2001). Motivation in language planning and language policy. Clevedon: Multilingual Matters. Agnihotri, R. K. (2007). Identity and multilinguality: The case of India. In A. B. M. Tsui \& J. W. Tollefson (Eds.), Language policy, culture and identity in Asian contexts (pp. 185-204). Mahwah, NJ: Lawrence Erlbaum.

Anand, K. (2013, Aug. 11). India speaks...780 ways. The Indian Express. Online version: http://archive. indianexpress.com/news/india-speaks...780-ways/1153717/.

Annamalai, E. (1990). Dimensions of bilingual education in India. New Language Planning Newsletter, 4(4), 1-3.

Annamalai, E. (2001). Managing multilingualism in India: Political and linguistic manifestation (Vol. 8). New Delhi, India: Sage.

Bailey, T., van Riezen, K., \& van Riezen, I. (1999). A sociolinguistic and educational survey of Kumaun. SIL International: Research Report.

Baker, C. (2003). Biliteracy and transliteracy in Wales: Language planning and the Welsh National Curriculum. In N. H. Hornberger (Ed.), Continua of biliteracy: An ecological framework for educational policy, research, and practice in multilingual settings (pp. 71-90). Clevedon: Multilingual Matters.

Baldridge, J. (2002, May). Reconciling linguistic diversity: The history and the future of language policy in India. Language in India 2. Retrieved April 18, 2003 from http://www.languageinindia.com/ may2002/baldridgelanguagepolicy.html. 
Bisht, S. S. (2005). Kumaon Himalaya ki Bolion ka Sarvekshan. New Delhi: Indian Publishers.

Blackledge, A. (2008). Language ecology and language ideology. In A. Creese, P. Martin \& N. H. Hornberger (Eds.), Encyclopedia of language and education, volume 9: Ecology of language (2nd ed., pp. 27-40). New York, NY: Springer.

Bourdieu, P. (1991). The production and reproduction of legitimate language. In J. B. Thompson (Ed.), Language and symbolic power (translated by B. Raymond \& M. Adamson) (pp. 43-65). Cambridge: Polity Press.

Canagarajah, A. S. (Ed.). (2005). Reclaiming the local in language policy and practice. Mahway, NJ: Lawrence Erlbaum.

Census of India. (1954). Paper No. 1: Languages-1951 census. Government of India.

Census of India. (1961). Vol I. Part II-C (ii) language tables. Government of India.

Census of India. (2008). Retrieved April 21, 2003 and February 11, 2008 from http://www.censusindia. net/.

Cooper, R. (1989). Language planning and social change. Cambridge: Cambridge University Press.

Creese, A., \& Martin, P. (Eds.). (2003). Multilingual classroom ecologies: Inter-relationships, interactions and ideologies. Clevedon: Multilingual Matters.

Das Gupta, J. (1970). Language conflict and national development. Berkeley: University of California Press.

Daswani, C. J. (Ed.). (2001). Language education in multilingual India. New Delhi: UNESCO.

Davis, K. A. (2014). Engaged language policy and practices. Language Policy, 13(2), 83-100.

Dua, H. R. (1985). Language planning in India. New Delhi: Harnam.

Dua, H. R. (1986). Language planning and linguistic minorities. In E. Annamalai, B. Jernudd, \& J. Rubin (Eds.), Language planning: Proceedings of an Institute (pp. 43-72). Mysore: Central Institute of Indian Languages.

Ekbote, G. (1984). A nation without a national language. Hyderabad: Hindi Prachar Sabha.

Ferguson, C. A. (1968). Language development. In J. Fishman, C. A. Ferguson \& J. Das Gupta (Eds.), Language problems of developing nations (pp. 27-35). New York: Wiley.

García, O. (2009). Bilingual education in the 21st century: A global perspective. Malden: Basil/ Blackwell.

García, O., \& Wei, L. (2014). Translanguaging: Language, bilingualism and education. New York: Palgrave Macmillan.

Grierson, G. A. (1903-1927). A linguistic survey of India. Delhi: Motilal Banarasidas.

Grierson, G. A. (1966). Linguistic survey of India (2nd ed.). Delhi: Motilal Banarsidas.

Groff, C. (2010). "Language, education, and empowerment: Voices of Kumauni young women in multilingual India." Publicly accessible Penn Dissertations. http://repository.upenn.edu/ edissertations/115.

Groff, C. (2013). Multilingual discourses and pedagogy in North India. In J. A. Shoba \& F. Chimbutane (Eds.), Bilingual education and language policy in the global South (pp. 190-206). London: Routledge.

Group on Minorities Education. (1991). Report on minorities education. New Delhi: Government of India Press.

Haugen, E. (1983). The implementation of corpus planning: Theory and practice. In J. Cobarrubias \& J. Fishman (Eds.), Progress in language planning: International perspectives (pp. 269-290). Berlin: Mouton.

Heller, M., \& Martin-Jones, M. (2001). Voices of authority: Education and linguistic difference. Westport, CT: Ablex.

Hornberger, N. (1994). Literacy and language planning. Language and Education, 8(1-2), 75-86.

Hornberger, N. H. (2002). Multilingual language policies and the continua of biliteracy: An ecological approach. Language Policy, 1(1), 27-51.

Hornberger, N. H. (2003). Continua of biliteracy: An ecological framework for educational policy, research, and practice in multilingual settings. Clevedon: Multilingual Matters.

Hornberger, N. H., \& Johnson, D. C. (2007). Slicing the onion ethnographically: Layers and spaces in multilingual language education policy and practice. TESOL Quarterly, 41(3), 509-532.

Irvine, J. T., \& Gal, S. (2000). Language ideology and linguistic differentiation. In P. V. Kroskrity (Ed.), Regimes of language: Ideologies, polities, and identities. Santa Fe: School of American Research.

Jayaram, B. D., \& Rajyashree, K. S. (2000). State official language policy implementation: A geolinguistic profile in sociolinguistic perspective. Mysore: Central Institute of Indian Languages. 
Jhingran, D. (2005). Language disadvantage: The learning challenge in primary education. New Delhi: S. B. Nangia APH.

Johnson, D. C. (2009). Ethnography of language policy. Language Policy, 8(2), 139-159.

Jørgensen, J. N. (2008). Polylingual languaging around and among children and adolescents. International Journal of Multilingualism, 5(3), 161-176.

Kaplan, R. B. (1989). Language planning vs. planning language. In C. H. Candlin \& T. F. McNamara (Eds.), Language, learning and community (pp. 193-203). Sydney: NCELTR.

Khubchandani, L. M. (1981). Multilingual education in India. Pune: Center for Communication Studies.

Khubchandani, L. M. (2001). Language demography and language education. In C. J. Daswani (Ed.), Language education in multilingual India. New Delhi: UNESCO.

Khubchandani, L. M. (2005, October 7). Mother-tongue education in pluralingual contexts. Paper presented at the Educational Linguistics Forum Brown Bag, Philadelphia, PA.

King, R. D. (1997). Nehru and the language politics of India. Delhi: Oxford University.

Kloss, H. (1967). Research possibilities on group bilingualism: A report. Quebec: International Center for Research on Bilingualism.

Kumar, A. (1985). Cultural and educational rights of the minorities under Indian Constitution. New Delhi: Deep \& Deep Publications.

Lewis, M. P., Gary, F. S., \& Charles D. F. (Eds.). (2014). Ethnologue: Languages of the world, seventeenth edition. Dallas, TX: SIL International. http://www.ethnologue.com.

Mahapatra, B. P. (1986). Language planning and census in India. In E. Annamalai, B. Jernudd, \& J. Rubin (Eds.), Language planning: Proceedings of an Institute (pp. 43-72). Mysore: Central Institute of Indian Languages.

Makoni, S., \& Pennycook, A. (Eds.). (2007). Disinventing and reconstituting languages. Clevedon: Multilingual Matters.

McCarty, T. L. (Ed.). (2011). Ethnography and language policy. London: Routledge.

Meganathan, R. (2011). Language policy in education and the role of English in India: From library language to language of empowerment. In H. Coleman (Ed.), Dreams and realities: Developing countries and the English language. London: British Council.

Mohanty, A. (2005, October). Perpetuating inequality: Language disadvantage and capability deprivation of tribal mother tongue speakers in India. Paper presented at the Cornell Conference on Language and Poverty, Ithaca, NY.

Mohanty, A. K. (2010). Languages, inequality and marginalization: Implications of the double divide in Indian multilingualism. International Journal of the Sociology of Language, 2010(205), 131-154.

Nahir, M. (1984). Language planning goals: A classification. Language Problems \& Language Planning, 8(3), 294-327.

National Council of Educational Research and Training (NCERT). (2005). National curriculum framework 2005. New Delhi: NCERT.

National Council of Educational Research and Training (NCERT). (2011). Program evaluation report: Multilingual education Orissa. New Delhi: NCERT.

Neustupny, J. V. (1974). Basic types of treatment of language problems. In J. Fishman (Ed.), Advances in language planning (pp. 37-48). The Hague: Mouton.

Pattanayak, D. P. (2001). Tribal languages in education. In C. J. Daswani (Ed.), Language education in multilingual India. New Delhi: UNESCO.

Pattanayak, D. P. (2003). Mother tongue: The problem of definition. In A. Ouane (Ed.), Towards a multilingual culture of education. Hamburg: UNESCO Institute of Education.

Rajagopalan, S. (2001). State and nation in South Asia. Boulder, CO: Lynne Rienner Publishers.

Ramanathan, V. (2005a). The English-vernacular divide: Postcolonial language politics and practice (Vol. 49). Clevedon: Multilingual Matters.

Ramanathan, V. (2005b). Rethinking language planning and policy from the ground up: Refashioning institutional realities and human lives. Current Issues in Language Planning, 6(2), 89-101.

Ricento, T. (2000). Historical and theoretical perspectives in language policy and planning. Journal of Sociolinguistics, 4(2), 196-213.

Ricento, T., \& Hornberger, N. H. (1996). Unpeeling the onion: Language planning and policy and the ELT professional. TESOL Quarterly, 30(3), 401-427.

Ruiz, R. (1984). Orientations in language planning. NABE Journal, 8(2), 15-34.

Saksena, B. R. (1972). Gandhiji's solution of the language problem of India. Bombay: Mahatma Gandhi Memorial Research Centre, Hindustani Prachar Sabha.

Sarker, A. (1964). Handbook of languages and dialects of India. Calcutta: Firma K. L. Muchopadhyay. 
Schiffman, H. F. (1996). Linguistic culture and language policy. New York: Routledge.

Schieffelin, B. B., Woolard, K. A., \& Kroskrity, P. V. (Eds.). (1998). Language ideologies: Practice and theory. New York: Oxford University.

Shamra, D. D. (1994). Linguistic geography of Kumaun Himalayas. New Delhi: Mittal.

Shapiro, M. C., \& Schiffman, H. F. (1981). Language and society in South Asia. Delhi: Motilal Banarsidas.

Sharma, B. N. (1985). Medium of instruction in India: A backgrounder based on official documents of the Government of India. New Delhi: Central Secretariat Library, Department of Culture.

Sharma, D. D. (1988). Kumauni language and dialects. In K. S. Valdiya (Ed.), Kumaun, land and people. Nainital: B.L. Consul for Gyanodaya Prakashan.

Singh, U. N. (2008, January 6). Keynote address. In 8th international conference on South Asian languages. Aligarh, India.

Skutnabb-Kangas, T., Phillipson, R., Mohanty, A., \& Panda, M. (Eds.). (2009). Social justice through multilingual education (Vol. 7). Bristol: Multilingual Matters.

Stewart, W. (1968). A sociolinguistic typology for describing national multilingualism. In J. A. Fishman (Ed.), Readings in the sociology of language (pp. 531-546). The Hague: Mouton.

Sutton, M., \& Levinson, B. (Eds.). (2001). Policy as practice: Toward a comparative sociocultural analysis of educational policy. Westport, CT: Ablex.

Vaish, V. (2008). Biliteracy and globalization: English language education in India (p. 126). Clevedon: Multilingual Matters.

Cynthia Groff earned her Ph.D. in Educational Linguistics at the University of Pennsylvania. She has conducted post-doctoral research through Université Laval and Universidad Autónoma MetropolitanaIztapalapa, funded by the National Academy of Education/Spencer Postdoctoral Fellowship. Her current affiliation is with Leiden University Centre for Linguistics. Her research interests include adequacy of education for linguistic minorities and the experiences and discourses of minority youth. 